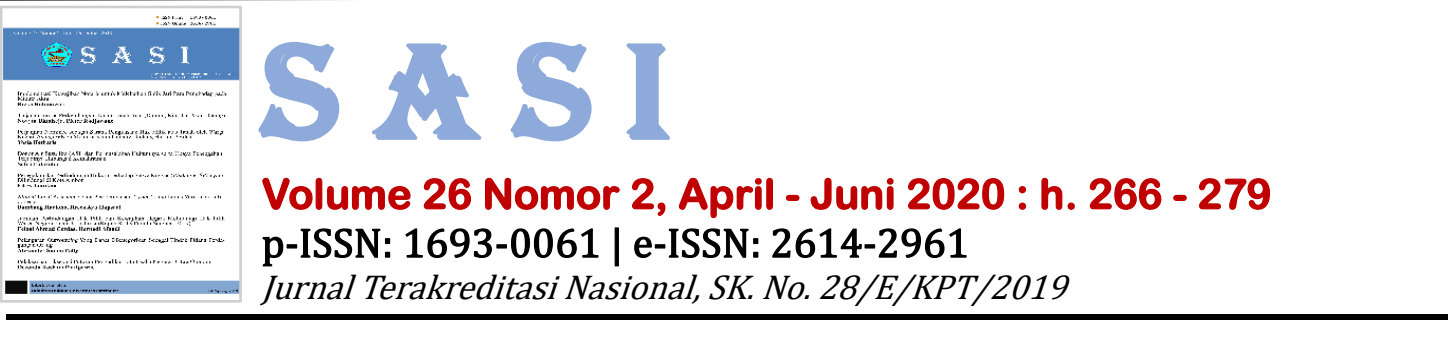

\title{
Kontroversi Putusan Mahkamah Konstitusi Membatalkan Kewenangan Komisi Yudisial Melakukan Rekrutmen Terhadap Hakim
}

\author{
Suparto Suparto \\ Fakultas Hukum Universitas Islam Riau, Pekanbaru, Indonesia \\ E-mail: suparto@law.uir.ac.id
}

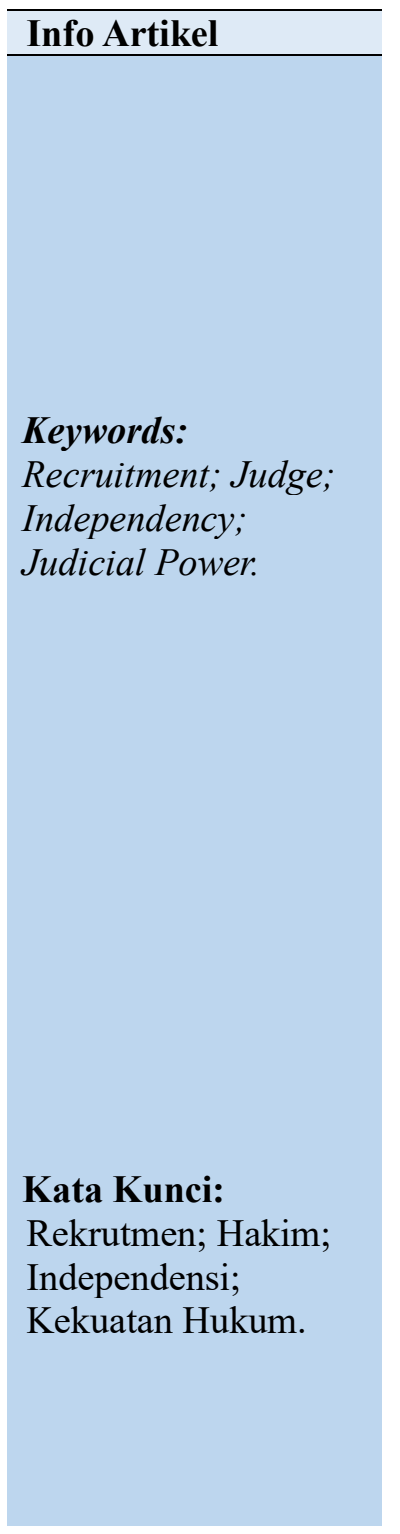

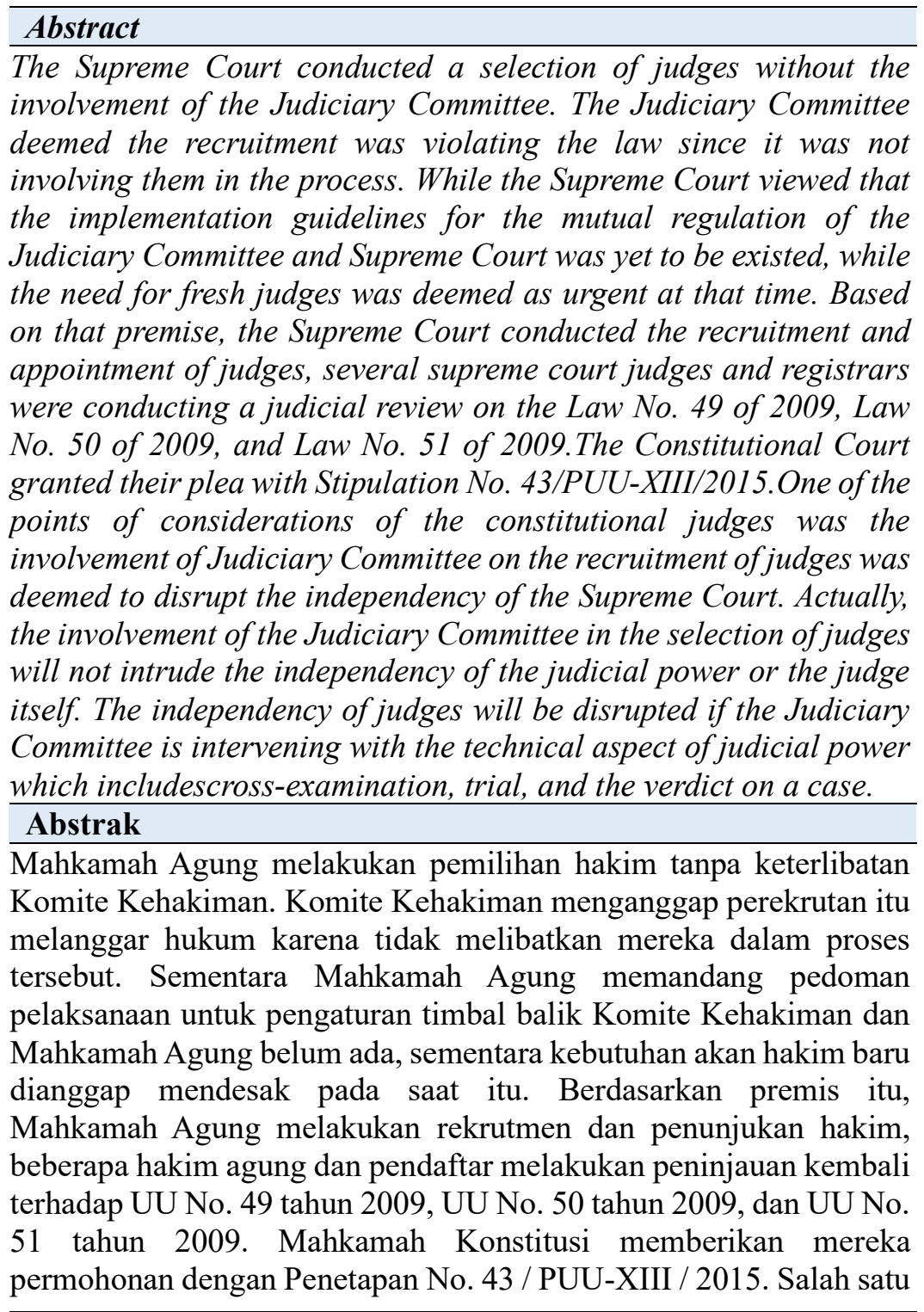


poin pertimbangan hakim konstitusi adalah keterlibatan Komite Kehakiman dalam rekrutmen hakim yang dianggap mengganggu independensi Mahkamah Agung. Sebenarnya, keterlibatan Komite Kehakiman dalam pemilihan hakim tidak akan mengganggu independensi kekuasaan kehakiman atau hakim itu sendiri. Independensi hakim akan terganggu jika Komite Kehakiman campur tangan dengan aspek teknis kekuasaan yudisial yang meliputi pemeriksaan silang, persidangan, dan putusan terhadap suatu kasus.

\section{A. PENDAHULUAN}

Setelah adanya putusan Mahkamah Konstitusi No. 05/PUU-IV/2006 yang mengamputasi kewenangan Komisi Yudisial (KY) dalam melakukan pengawasan terhadap terhadap perilaku hakim konstitusi, KY memperoleh tambahan kewenangan berdasarkan UU No.49 Tahun 2009 Tentang Perubahan Kedua Atas UU No. 2 Tahun 1986 Tentang Peradilan Umum, UU No.50 Tahun 2009 Tentang Perubahan Kedua Atas UU No. 7 Tahun 1989 Tentang Peradilan Agama, UU No.51 Tahun 2009 Tentang Perubahan Kedua Atas UU No. 5 Tahun 1986 Tentang Peradilan Tata Usaha Negara, yaitu melakukan proses seleksi pengangkatan hakim bersama dengan Mahkamah Agung. ${ }^{1}$ Akan tetapi dalam pelaksanaannya hal ini tidak berjalan mulus.

Persoalan pengangkatan hakim menjadi permasalahan tersendiri antara Mahkamah Agung dan Komisi Yudisial. Persoalan ini muncul pertama kali pada tahunn 2010 ketika Mahkamah Agung melakukan seleksi hakim tanpa melibatkan Komisi Yudisial. Komisi Yudisial menganggap bahwa pengangkatan hakim tanpa melibatkan Komisi Yudisial adalah melanggar Undang-Undang (UU No.49 Tahun 2009 Tentang Perubahan Kedua Atas UU No. 2 Tahun 1986 Tentang Peradilan Umum, UU No.50 Tahun 2009 Tentang Perubahan Kedua Atas UU No. 7 Tahun 1989 Tentang Peradilan Agama, UU No.51 Tahun 2009 Tentang Perubahan Kedua Atas UU No. 5 Tahun 1986 Tentang Peradilan Tata Usaha Negara). Karena disitu jelas disebutkan bahwa pengangkatan hakim dilakukan secara bersama antara Komisi Yudisial dan Mahkamah Agung. ${ }^{2}$

Pihak Mahkamah Agung berpandangan bahwa aturan pelaksanaan berupa peraturan bersama antara Komisi Yudisial dan Mahkamah agung belum ada, sedangkan kebutuhan akan hakim sangat mendesak untuk segera dipenuhi sehingga ia merasa perlu untuk melakukan pengangkatan hakim. ${ }^{3}$ Setelah melalui beberapa pertemuan akhirnya dicapai kesepakatan bahwa untuk menyelamatkan/melegalkan calon hakim yang terlanjur diterima melalui seleksi yang dilaksanakan oleh Mahkamah Agung dibuatlah peraturan bersama antara Mahkamah Agung dan Komisi Yudisial No.01/PB/MA/IX/2012 dan No. 01/PB/P.KY/09/2012 tentang seleksi pengangkatan calon hakim yang bersifat sementara. Dalam peraturan bersama tersebut intinya adalah Mahkamah Agung melalui BADIKLAT bertugas untuk menyelenggarakan pendidikan dan Komisi Yudisial memiliki kewenangan dalam hal pembekalan Kode Etik dan Pedoman Perilaku Hakim serta pemantauan proses

1 Permana, T.C.I. (2014). "Eksistensi dan Peran Komisi Yudisial : Pengkajian Konteks Filosofi, Sejarah dan Tujuan Pembentukannya Dalam Dinamika Ketatanegaraan Indonesia”, Jurnal Hukum dan Peradilan, 3 (1), 85-100, h. 96.

2 Mukuan, C. (2016) "Kewenangan Komisi Yudisial Dalam Perekrutan Hakim Menurut UndangUndang No. 22 Tahun 2004 jo Undang-Undang No. 18 Tahun 2011 Tentang Komisi Yudisial”, Jurnal Lex Administratum, IV (1), 5-12, h. 5.

3 Suparto, (2015). Kedudukandan Kewenangan Komisi Yudisial Sebagai Lembaga Negara Pelaku Pengawasan Eksternal Terhadap Hakim Di Indonesia, dalam buku Syafrinaldi (ed.) "Hukum dan Teori Dalam Realita Masyarakat", Pekanbaru : UIR Press, h. 78. 
magang. ${ }^{4}$

Pertemuan antara Mahkamah Agung dan Komisi Yudisial untuk membahas masalah seleksi pengangkatan hakim ini memang berjalan cukup lama, hal ini disebabkan karena tidak hanya membahas persoalan teknis atau tata cara seleksi pengangkatan calon hakim. Akan tetapi yang lebih krusial adalah soal status dari seorang hakim apakah ia Pegawai Negeri Sipil atau bukan. Sehingga harus melibatkan kementerian PAN dan RB, Badan Kepegawaian Negara dan Kementerian Keuangan. Proses yang cukup panjang ini , menghambat pihak Mahkamah Agung untuk melakukan seleksi pengangkatan hakim padahal di pihak lain Mahkamah Agung sangat membutuhkan hakim. ${ }^{5}$

Akhirnya di awal tahun 2015 beberapa orang hakim agung dan panitera Mahkamah Agung melakukan pengujian terhadap UU No. 49 Tahun 2009 Tentang Perubahan Kedua Atas UU No. 2 Tahun 1986 Tentang Peradilan Umum, UU No. 50 Tahun 2009 Tentang Perubahan Kedua Atas UU No. 7 Tahun 1989 Tentang Peradilan Agama, UU No. 51 Tahun 2009 Tentang Perubahan Kedua Atas UU No. 5 Tahun 1986 Tentang Peradilan Tata Usaha Negara. ${ }^{6}$ Berdasarkan putusan No. 43/PUU-XIII/2015 Mahkamah Konstitusi mengabulkan permohonan pemohon. Berdasarkan uraian tersebut penulis membuat rumusan masalah Bagaimana pertimbangan Hakim Konstitusi dalam memutus perkara No. 43/PUU-XIII/2015 ?

\section{B. PEMBAHASAN}

Putusan Mahkamah Konstitusi (MK) No. 43/PUU-XIII/2013 merupakan pengujian terhadap UU No.49 Tahun 2009 Tentang Perubahan Kedua Atas UU No. 2 Tahun 1986 Tentang Peradilan Umum, UU No.50 Tahun 2009 Tentang Perubahan Kedua Atas UU No. 7 Tahun 1989 Tentang Peradilan Agama, UU No.51 Tahun 2009 Tentang Perubahan Kedua Atas UU No. 5 Tahun 1986 Tentang Peradilan Tata Usaha Negara yang dilakukan oleh beberapa orang hakim agung dan panitera Mahkamah Agung (MA). Alasan diajukannya pengujianoleh pemohon adalah bahwa Pasal 24 ayat (1) UUD 1945 menyatakan, "Kekuasaan Kehakiman merupakan kekuasaan yang merdeka untuk menyelenggarakan peradilan guna menegakkan hukum dan keadilan". Penjabaran lebih lanjut mengenai pengertian tentang Kekuasaan Kehakiman diatur dalam Undang-Undang Nomor 48 Tahun 2009 tentang Kekuasaan Kehakiman. Menurut Pasal 1 angka (1) Undang-Undang Kekuasaan Kehakiman : "Kekuasaan Kehakiman adalah Kekuasaan negara yang merdeka untuk menyelenggarakan peradilan guna menegakkan hukum dan keadilan berdasarkan Pancasila dan Undang-Undang Dasar Negara Republik Indonesia Tahun 1945, demi terselenggaranya Negara Hukum Republik Indonesia”.

Kata "merdeka" dalam ketentuan tersebut, memiliki arti : (bebas dari perhambaan, penjajahan, dsb); berdiri sendiri; atau tidak terkena atau lepas dari tuntutan; atau tidak terikat atau tergantung pada pihak tertentu; leluasa (Kamus Bahasa Indonesia yang disusun oleh Tim Penyusun Kamus Pusat Bahasa Departemen Pendidikan Nasional, Jakarta, 2008, hal 1015). Dengan demikian dapatlah dirumuskan bahwa yang dimaksud

4 Suparto, (2017). Dinamika Hubungan Antara Mahkamah Agung Dengan Komisi Yudisial Republik Indonesia, Jakarta : Bina Karya, h.210.

${ }_{5}^{5}$ Suparto, (2018). Mengkritisi PutusanMahkamahAgung Tentang Hak Uji Materiil Surat Keputusan Bersama (SKB) Ketua Mahkamah Agung dengan Ketua Komisi Yudisial Tentang Kode Etik dan Perilaku Hakim, dalam buku Syafrinaldi (ed.) "Problematika Hukum Indonesia Teori dan Praktek", Depok : Raja Grafindo Persada, h. 110.

${ }^{6}$ Hakim Agung dan Panitera yang mengajukan pengujian adalah Imam Soebechi, Suhadi, Abdul Manan, Yulius, Burhan Dahlan dan Soeroso Ono. 
dengan "Kekuasaan Yang Merdeka" adalah kekuasaan yang bebas, berdiri sendiri dan tidak tergantung pada pihak tertentu.

Selanjutnya ketentuan Pasal 21 ayat (1) Undang-Undang Nomor 48 Tahun 2009 menyatakan bahwa : "Organisasi, administrasi dan finansial Mahkamah Agung dan badan peradilan yang berada dibawahnya berada di bawah kekuasaan Mahkamah Agung". Sedangkan ayat (2)-nya berbunyi :'Ketentuan mengenai organisasi, administrasi dan finansial badan peradilan sebagaimana dimaksud pada ayat (1) untuk masing-masing lingkungan peradilan diatur dalam undang-undang sesuai dengan kekhususan lingkungan peradilan masing-masing”.

Sehubungan hal tersebut, terkait dengan pengangkatan hakim, harus dipahami bahwa kewenangan Komisi Yudisial dam ketentuan Pasal 24B ayat (1) UUD 1945 hanya menyangkut kewenangan untuk mengusulkan pengangkatan hakim agung. Kewenangan Komisi Yudisial tersebut adalah kewenangan yang bersifat limitatif, yang mengandung arti bahwa kewenangan Komisi Yudisial hanya terbatas pada "mengusulkan pengangkatan hakim agung", bukan terhadap proses seleksi pengangkatan hakim pada Peradilan Umum, Peradilan Agama dan Peradilan Tata Usaha Negara. Dengan demikian, perluasan makna "Pengangkatan Hakim Agung" pada Pasal 24B ayat (1) UUD 1945 dengan memperluas kewenangan Komisi Yudisial dalam proses seleksi pengangkatan hakim pada badan peradilan dibawah Mahkamah Agung dalam ketentuan Pasal 14A ayat (2) Undang-Undang Nomor 49 Tahun 2009 juncto Pasal 13A ayat (2) Undang-Undang Nomor 50 Tahun 2009 juncto Pasal 14A ayat (2) Undang-Undang Nomor 51 Tahun 2009 adalah bertentangan dengan UUD 1945 tersebut diatas. Hal ini bertentangan pula dengan prinsip hukum yang berlaku secara universal yakni prinsip Lex Certa, suatu materi dalam peraturan perundang-undangan tidak dapat diperluas atau ditafsirkan lain selain yang tertulis dalam peraturan perundangan (Lex Stricta) atau dengan kata lain prinsip suatu ketentuan atau perundang-undangan tidak dapat diberikan perluasan selain ditentukan secara tegas dan jelas menurut peraturan perundang-undangan. Selain itu, perluasan kewenangan Komisi Yudisial tersebut adalah inkonstitusional karena tidak sesuai dengan prinsip Lex Superior Derogat Lex Inferior.

Bahwa hak dan kewenangan konstitusional para Pemohon dalam kedudukannya sebagai Hakim Agung dan Panitera pada Mahkamah Agung sekaligus sebagai Pengurus Pusat Ikatan Hakim Indonesia (IKAHI), untuk mendapatkan jaminan kemerdekaan dan kemandirian peradilan yang menentukan independensi hakim telah dirugikan dengan berlakunya Pasal 14A ayat (2) dan ayat (3) Undang-Undang Nomor 49 Tahun 2009 juncto Pasal 13A ayat (2) dan ayat (3) Undang-Undang Nomor 50 Tahun 2009 juncto Pasal 14A ayat (2) dan ayat (3) Undang-Undang Nomor 51 Tahun 2009.

Menjamin terwujudnya independensi hakim, menurut mahkamah, memerlukan lembaga yang independen pula, agar dapat menjamin para hakim dalam menjalankan tugas dan fungsinya dengan sebaik-baiknya, yang antara lain sebagaimana diatur dalam Pasal 21 ayat (1) Undang-Undang Nomor 48 Tahun 2009 tentang Kekuasaan Kehakiman yang menyatakan, "Organisasi, administrasi, dan finansial Mahkamah Agung dan badan peradilan yang berada di bawahnya berada di bawah kekuasaan Mahkamah Agung”.

Salah satu tuntutan reformasi adalah menyangkut reformasi di bidang peradilan yakni adanya kekuasaan kehakiman yang merdeka, bebas dari intervensi maupun pengaruh kekuasaan lain, termasuk dalam hal organisasi, administrasi dan keuangan. Tuntutan tersebut kemudian ditindaklanjuti melalui Undang-Undang Nomor 35 Tahun 1999 tentang Perubahan Atas Undang-Undang Nomor 14 Tahun 1970 tentang KetentuanKetentuan Pokok Kekuasaan Kehakiman. Melalui perubahan Undang-Undang Nomor 14 
Tahun 1970 inilah yang menjadi cikal bakal lahirnya sistem peradilan satu atap (one roof system) yaitu baik menyangkut teknis yudisial maupun organisasi, administrasi dan finansial berada di dibawah satu atap Mahkamah Agung.

Upaya dalam mewujudkan kekuasaan kehakiman yang merdeka dalam bentuk peradilan satu atap dibawah Mahkamah Agung tersebut, akhirnya benar-benar menjadi kenyataan ketika tahun 2001 dilakukan perubahan terhadap Pasal 24 UUD 1945 yang kemudian disusul oleh lahirnya Undang-Undang Nomor 4 Tahun 2004 tentang Kekuasaan Kehakiman yang dicabut dan dinyatakan tidak berlaku oleh Undang-Undang Nomor 48 Tahun 2009 tentang Kekuasaan Kehakiman.

Berdasarkan pertimbangan tersebut diatas, menurut Mahkamah, sistem peradilan yang diamanatkan dan dikehendaki oleh konstitusi dalam melaksanakan kekuasaan kehakiman, yang tugasnya tidak saja sekedar menegakkan hukum, tetapi sekaligus menegakkan keadilan telah terpenuhi. Dengan sistem dan mekanisme seperti itu, pencari keadilan telah dilindungi dalam mendapatkan hakim yang bebas dan tidak memihak.

Pasal 3 ayat (2) Undang-Undang Nomor 48 Tahun 2009 tentang Kekuasaan Kehakiman menegaskan, "segala campur tangan dalam urusan peradilan oleh pihak lain di luar kekuasaan kehakiman dilarang, kecuali dalam hal-hal sebagaimana dimaksud dalam Undang-Undang Dasar Negara Republik Indonesia Tahun 1945”. Ketentuan yang sama juga terdapat dalam Undang-Undang Kekuasaan Kehakiman sebelumnya yaitu dalam Pasal 4 ayat (3) Undang-Undang Nomor 4 Tahun 2004 tentang Kekuasaan Kehakiman yang menyatakan, "segala campur tangan dalam urusan peradilan oleh pihak lain di luar kekuasaan kehakiman dilarang, kecuali dalam hal-hal sebagaimana dimaksud dalam Undang-Undang Dasar Negara Republik Indonesia Tahun 1945”.

Komisi Yudisial yang lahir dalam perubahan UUD 1945, kewenangannya telah ditegaskan dalam Pasal 24B ayat (1) UUD yang berbunyi, "Komisi Yudisial bersifat mandiri yang berwenang mengusulkan pengangkatan hakim agung dan mempunyai wewenang lain dalam rangka menjaga dan menegakkan kehormatan, keluhuran martabat, serta perilaku hakim".

Putusan Mahkamah Konstitusi Nomor. 005/PUU-IV/2006, tanggal 23 Agustus 2006 Mahkamah telah menafsirkan frasa "wewenang lain dalam rangka menjaga dan menegakkan kehormatan, keluhuran martabat, serta perilaku hakim" bahwa “... walaupun dalam batas-batas tertentu dapat diartikan sebagai pengawasan, bukanlah kewenangan untuk melakukan pengawasan terhadap lembaga peradilan melainkan terhadap individu fungsionaris hakim. Sebagai pelaku kekuasaan kehakiman, baik Mahkamah Agung dan peradilan dibawahnya serta Mahkamah Konstitusi merupakan kekuasaan yang merdeka (Pasal 24 UUD 1945) sehingga dalam melaksanakan kewenangan justisialnya lembaga peradilan tidak dapat diawasi oleh lembaga negara lain". Suatu norma yang telah dibahas dan diputus dalam rapat BP MPR maupun MPR dan kemudian ditolak, menurut Mahkamah tidak boleh dijadikan norma dalam Undang-Undang kecuali dilakukan melalui proses perubahan Undang-Undang Dasar sebagaimana diatur dalam Pasal 3 ayat (1) dan Pasal 37 UUD 1945. Frasa "wewenang lain" dalam Pasal 24B ayat (1) UUD 1945 adalah semata dalam rangka menjaga dan menegakkan kehormatan, keluhuran martabat, serta perilaku hakim, tidak dapat diperluas dengan tafsiran lain. UUD 1945 tidak memberi kewenangan kepada pembuat Undang-Undang untuk memperluas kewenangan Komisi Yudisial.

Meskipun dalam Pasal 24 UUD 1945 tidak menyebutkan secara tersurat mengenai kewenangan Mahkamah Agung dalam proses seleksi dan pengangkatan calon hakim dari lingkungan peradilan umum, peradilan agama, dan peradilan tata usaha negara, akan 
tetapi dalam ayat (2) dari Pasal 24 telah secara tegas menyatakan ketiga Undang-Undang yang diajukan Pemohon dalam perkara tersebut berada dalam lingkungan kekuasaan kehakiman di bawah Mahkamah Agung. Lagipula apabila dihubungkan dengan sistem peradilan "satu atap", menurut Mahkamah, seleksi dan pengangkatan calon hakim pengadilan tingkat pertama menjadi kewenangan Mahkamah Agung. Melalui putusan Mahkamah Konstitusi No. 43/PUU-XIII/2015, Mahkamah Konstitusi mengabulkan permohonan para pemohon.

Menurut Pantja Astawa UUD 1945 memberi kewenangan kepada Komisi Yudisial sebagaimana terumus dalam ketentuan Pasal 24B ayat (1), yaitu :

1) Wewenang untuk mengusulkan pengangkatan Hakim Agung, dan

2) Wewenang lain dalam menjaga dan menegakkan kehormatan, keluhuran martabat, serta perilaku hakim.

Pemaknaan atas norma yang terkandung dalam ketentuan Pasal 24B ayat (1) UUD 1945 harus dikembalikan pada dasar pemikiran yang tersimpul dari wethistories sebagaimana yang telah diuraikan. Dengan perkataan lain, makna norma yang terkandung dalam ketentuan Pasal 24B ayat (1) UUD 1945 sudah "clear" dan tidak dapat lagi ditafsirkan lain. Hal ini sejalan dengan pendapat Jimly Asshiddiqie yang menyatakan : Jika suatu ketentuan sudah dirumuskan secara "expressis verbis" dengan "phraseology" yang jelas dan tidak bersifat "ambiguous" serta mengandung hanya satu pengertian atau penafsiran tunggal saja, tidaklah terbuka bagi pengadilan untuk menafsirkannya secara lain. Jika hakim berbuat demikian, berarti dia sudah berubah menjadi pembentuk undangundang atau legislator.

Pendapat diatas sekaligus menegaskan bahwa ketentuan Pasal 24B ayat (1) UUD 1945 hanya memberikan kewenangan kepada Komisi Yudisial untuk mengusulkan pengangkatan Hakim Agung selain kewenangan untuk melakukan pengawasan etik (dalam rangka menjaga dan menegakkan kehormatan, keluhuran martabat, serta perilaku hakim), maka berdasarkan ketentuan Pasal 24B ayat (1) UUD 1945, Komisi Yudisial tidak memiliki kewenangan (onbevoegheid) untuk ikut dalam seleksi pengangkatan hakim. ${ }^{7}$

Hal senada disampaikan oleh Yusril Ihza, bahwa kewenangan Komisi Yudisial telah diatur dengan jelas di dalam norma Pasal 24B ayat (1) UUD yang menyatakan, "Komisi Yudisial bersifat mandiri yang berwenang mengusulkan pengangkatan hakim agung dan mempunyai wewenang lain dalam rangka menjaga dan menegakkan kehormatan, keluhuran martabat, serta perilaku hakim". Kewenangan Komisi Yudisial sebagaimana dirumuskan dalam pasal ini adalah limitatif, tidak lebih dan tidak kurang dan UndangUndang Dasar tidak memberikan kewenangan kepada pembentuk Undang-Undang untuk memperluas kewenangan Komisi Yudisial, kecuali apa yang secara tegas telah dinyatakan didalam norma Pasal 24B ayat (1) tersebut. Perintah konstitusi untuk merumuskan secara lebih detil terkait dengan Komisi Yudisial bukanlah mengenai kewenangannya, melainkan berkaitan dengan, "susunan, kedudukan dan keanggotaan Komisi Yudisial diatur dengan Undang-Undang” sebagaimana dirumuskan oleh norma Pasal 24B ayat (4) UUD 1945.

Memang benar adanya bahwa selama proses pembahasan amandemen tahap kedua

7 Keterangan Ahli Pantja Astawa dalam Sidang Perkara No. 43/PUU-XIII/2015 tentang Pengujian UU No. 49 Tahun 2009 Tentang Perubahan Kedua Atas UU No. 2 Tahun 1986 Tentang Peradilan Umum, UU No. 50 Tahun 2009 Tentang Perubahan Kedua Atas UU No. 7 Tahun 1989 Tentang Peradilan Agama dan UU No. 51 Tahun 2009 Tentang Perubahan Kedua Atas UU No. 5 Tahun 1986 Tentang Peradilan Tata Usaha Negara. 
UUD 1945, terdapat beberapa anggota MPR antara lain, Harjono, Jacob Tobing dan Hamdan Zoelva yang membahas kemungkinan Komisi Yudisial untuk ikut menyeleksi calon hakim tingkat pertama dan banding, namun usulan-usulan mereka itu tidak disepakati baik oleh PAH maupun oleh sidang paripurna MPR. Apa yang disepakati oleh Komisi Yudisial hanyalah dalam proses seleksi Hakim Agung saja, tidak hakim-hakim yang lain. Semangat yang menggelora di tahun-tahun pertama reformasi sejauh menyangkut bab peradilan adalah keharusan kemandirian dan kemerdekaan badan-badan peradilan, baik dalam hal organisasi, personil dan keuangan, maupun kemerdekaan dalam menjalankan tugas dan kewenangannya. Oleh karena itulah, pada tahun 2003, Departemen Kehakiman dan HAM mulai merancang Undang-Undang untuk "menyatuatapkan" badan-badan peradilan kepada Mahkamah Agung, dengan konsekuensi Pemerintah dalam hal ini Departemen Kehakiman dan HAM, Departemen Agama dan Mabes TNI tidak lagi menangani urusan organisasi, administrasi, personil dan keuangan badan-badan peradilan, yang kita warisi sejak zaman Hindia Belanda, tetapi menyerahkan seluruh kewenangan itu kepada Mahkamah Agung. Dengan penyerahan itu, Pemerintah pada waktu itu berkeinginan agar badan-badan peradilan kita benar-benar mandiri dalam hal menentukan personil, mengurus organisasi, administrasi dan anggaran, serta merdeka dalam menjalankan tugas dan kewenangannya tanpa ada campur tangan Pemerintah lagi. ${ }^{8}$

Menurut Mahkamah Konstitusi adalah proses seleksi hakim haruslah dilakukan sendiri oleh Mahkamah Agung agar independensi kekuasaan kehakiman dapat terjaga. Mahkamah Konstitusi berpendapat pelibatan Komisi Yudisial adalah bentuk intervensi terhadap kekuasaan kehakiman. Tetapi logika dari Mahkamah Konstitusi itu dapat dibantah dengan kewenangan dalam pengisian hakim agung dan hakim konstitusi. UUD 1945 justru mendesain pengisian hakim agung sebagai kewenangan utama Komsi Yudisial dan hakim Mahkamah Konstitusi diisi dengan melibatkan tiga lembaga : Presiden, Dewan Perwakilan Rakyat dan Mahkamah Agung. ${ }^{9}$

Pendapat senada disampaikan oleh Moh. Mahfud MD, ia berpendapat bahwa kehadiran Komisi Yudisial dengan segala fungsi dan kewenangannya, termasuk dalam ikut proses seleksi pengangkatan hakim bersama dengan Mahkamah Agung, justru dimaksudkan untuk membangun lembaga yudikatif yang kuat sebagai simbol supremasi hukum. Kehadiran Komisi Yudisial yang dengan sadar sesadar-sadarnya telah diberi wewenang oleh pembentuk Undang-Undang untuk ikut melakukan proses seleksi pengakatan hakim dari berbagai lingkuangan peradilan di Mahkamah Agung sama sekali tidak mengurangi atau mengganggu prinsip kekuasaan kehakiman yang "merdeka" sebagaimana yang dimaksud oleh Pasal 24 ayat (1) UUD 1945. Pemberian wewenang kepada Komisi Yudisial untuk ikut melakukan proses seleksi pengangkatan hakim itu justru dimaksudkan untuk memperkuat tampilnya lembaga yudikatif yang "merdeka" plus kuat, bersih dan profesional. Istilah kekuasaan kehakiman yang merdeka harus diartikan pada dua hal utama. Pertama, MA sebagai lembaga negara secara struktural bersifat merdeka dalam arti kelembagaannya terpisah dan tidak berada di bawah struktur kekuasaan lembaga negara yang lain. Dalam bahasa akademis kemerdekaan seperti ini disebut independensi kekuasaan kehakiman. Kedua, hakim-hakim disemua lembaga

8 Keterangan Ahli Yusril Ihza Mahendra dalam Sidang Perkara No. 43/PUU-XIII/2015 tentang Pengujian UU No. 49 Tahun 2009 Tentang Perubahan Kedua Atas UU No. 2 Tahun 1986 Tentang Peradilan Umum, UU No. 50 Tahun 2009 Tentang Perubahan Kedua Atas UU No. 7 Tahun 1989 Tentang Peradilan Agama dan UU No. 51 Tahun 2009 Tentang Perubahan Kedua Atas UU No. 5 Tahun 1986 Tentang Peradilan Tata Usaha Negara.

9 Ulya, Z. (2016). "Pembatalan Kewenangan Komisi Yudisial Dalam Rekruitmen HakimDikaitkan Dengan Konsep Independensi Hakim (Studi Putusan Mahkamah Konstitusi Nomor 43/PUU-XIII/2015", Jurnal Mimbar Hukum, 28 (3), 482-496, h. 493. 
yudikatif dalam "memeriksa dan memutus" perkara yang ditanganinya harus bebas dari tekanan apapun sehingga secara leluasa mereka bisa memutus dengan adil dan tidak memihak. Dalam bahasa akademis kemerdekaan yang melekat pada hakim seperti ini biasa disebut sebagai imparsialitas. Kehadiran KY dengan semua wewenang konstitusional dan legalnya, termasuk ikut dalam proses seleksi pengangkatan hakim, dilihat dari sudut apapun tidaklah mengganggu prinsip kemerdekaan kekuasaan kehakiman, baik kemerdekaan dalam arti independensi MA maupun kemerdekaan dalam arti imparsialitas hakim-hakimnya. Tidak ada logika yang bisa menjelaskan bahwa kewenangan KY untuk bersama MA melakukan proses seleksi pengangkatan hakim itu telah mengganggu, apalagi melanggar prinsip kemerdekaan lembaga yudikatif. ${ }^{10}$

Sebetulnya keterlibatan Komisi Yudisial dalam proses seleksi pengangkatan hakim Pengadilan Negeri, hakim Pengadilan Tata Usaha Negara, hakim Pengadilan Agama yang dilakukan bersama-sama dengan Mahkamah Agung tidaklah mengganggu administrasi, organisasi maupun finansial pengadilan sepanjang keterlibatan Komisi Yudisial dalam memberikan pemahaman kode etik dan pedoman perilaku hakim bagi calon hakim yang telah dinyatakan lulus dalam proses seleksi sebagai calon pegawai negeri sipil. ${ }^{11}$

Pendapat senada disampaikan oleh Saldi Isra, Menurutnya besarnya arus pemikiran peran Komisi Yudisial dalam proses seleksi hakim, dalam draf rumusan Pasal 24C ayat (1) yang disampaikan oleh Jacob Tobing pada Rapat BP MPR ke-5 pada 23 Oktober 2001 di hadapan Ketua MPR Amin Rais. Dari rumusan usulan tersebut dapat dibaca : Komisi Yudisial bersifat mandiri yang berwenang mengusulkan pengangkatan dan pemberhentian Hakim Agung dan hakim lain (dengan memerhatikan masukan dari masyarakat atau berdasarkan masukan dari masyarakat). Begitu kuatnya keinginan ini, konstruksi draft usul Pasal 24C ayat (1) sama sekali tak menyediakan alternatif lain. Sekalipun dalam pembahasan ketika itu masih ada pendapat yang menghendaki wewenang Komisi Yudisial harus diberi catatan, namun pendapat yang menghendaki catatan dan pendalaman sangat minoritas ditengah arus besar yang ada. Karena itu dalam pembahasan akhir, rumusan-rumusan yang dikemukakan Jacob Tobing tidak mengalami perubahan.

Meski dalam rumusan final terjadi perubahan menjadi Komisi Yudisial bersifat mandiri yang berwenang mengusulkan pengangkatan Hakim Agung dan mempunyai wewenang lain dalam rangka menjaga dan menegakkan kehormatan, keluhuran martabat, serta perilaku hakim, namun perlu dicatat bahwa ide yang berkembang ditampung dalam adanya frasa "mempunyai wewenang lain" sebagaimana termaktub dalam Pasal 24B ayat (1) UUD 1945. Kalau dibaca dan dilacak dalam risalah perubahan UUD 1945, tidak ada penjelasan memadai ihwal munculnya frasa tersebut dan hilangnya frasa "mengusulkan pengangkatan dan pemberhentian Hakim Agung dan Hakim lain (dengan memerhatikan masukan dari masyarakat atau berdasarkan masukan dari masyarakat)". Dari penelurusan risalah juga, pernah muncul ide frasa "mempunyai wewenang lain dalam rangka..." tersebut. Namun ide ini diikuti dengan penegasan bahwa hal ini terkait juga dengan wewenang Komisi Yudisial dalam rekruitmen hakim. Artinya bilamana hendak diikuti

10 Keterangan Ahli Moh. Mahfud MD. dalam Sidang Perkara No. 43/PUU-XIII/2015tentang Pengujian UU No. 49 Tahun 2009 Tentang Perubahan Kedua Atas UU No. 2 Tahun 1986 Tentang Peradilan Umum, UU No. 50 Tahun 2009 Tentang Perubahan Kedua Atas UU No. 7 Tahun 1989 Tentang Peradilan Agama dan UU No. 51 Tahun 2009 Tentang Perubahan Kedua Atas UU No. 5 Tahun 1986 Tentang Peradilan Tata Usaha Negara.

11 Sihaloho, M. (2015). "Seleksi Pengangkatan Hakim Dalam Sistem Peradilan Indonesia : Kajian Putusan Mahkamah Konstitusi Nomor. 43/PUU-XII/2015”, Jurnal Wawasan Hukum, 33 (2), 204-218, h. 217. 
semangat para pengubah UUD 1945, frasa "mempunyai wewenang lain" tersebut sejalan dengan wewenang Komisi Yudisial dalam proses rekruitmen calon hakim. Dan yang jauh lebih penting, kehadiran aturan ini tidak menabrak ketentuan apapun dalam UUD 1945.

Perdebatan di sekitar kehadiran Komisi Yudisial tersebut, lembaga ini dengan segala wewenang termasuk dalam proses seleksi calon hakim adalah semangat yang tertampung dan tertuang dalam pemikiran para pengubah UUD 1945. Kalaupun kemudian gagasan tersebut tidak muncul secara eksplisit dalam Pasal 24B ayat (1) UUD 1945, adalah sebuah kekeliruan besar dan mendasar bahwa perintah Undang-Undang melibatkan Komisi Yudisial dalam menyeleksi calon hakim sebagai ide atau norma yang dinilai bertentangan dengan UUD 1945 atau inkonstitusional. Bila boleh menyederhanakan, adanya frasa "mempunyai wewenang lain" dalam Pasal 24B ayat (1) tersebut adalah untuk memberi ruang kepada pembentuk Undang-Undang dalam melakukan pilihan hukum di tingkat Undang-Undang untuk mendesain Komisi Yudisial.

Para pembentuk Undang-Undang telah melakukan langkah dan pilihan yang tepat. Bagaimanapun, pada saat undang-undang memberikan wewenang pada Komisi Yudisial terlibat dalam proses rekruitmen calon hakim, pembentuk undang-undang dapat dinilai telah menjemput kembali semangat dan arus besar yang dikehendaki mereka (paling tidak mayoritas) yang terlibat dalam perubahan UUD 1945, utamanya mereka yang tergabung dalam PAH reformasi kekuasaan hakim. Karena itu, menjadi sebuah kekeliruan yang amat mendasar seandainya ada pendapat yang mengatakan bahwa keterlibatan Komisi Yudisial dalam proses rekruitmen calon hakim dapat mengganggu independensi kekuasaan kehakiman. Bahkan dalam batas penalaran yang wajar, melibatkan Komisi Yudisial dalam seleksi calon hakim dapat menjadi strategi pembentuk undang-undang mewujudkan amanat Pasal 24 ayat (1) UUD 1945 yang menyatakan bahwa kekuasaan kehakiman merupakan kekuasaan yang merdeka untuk menyelenggarakan peradilan guna menegakkan hukum dan keadilan. Bagaimanapun dengan proses seleksi yang berkualitas, diharapkan dapat dihasilkan calon hakim yang berkualitas pula. ${ }^{12}$

Logika yang dibangun oleh hakim konstitusi bahwa apabila Komisi Yudisial ikut melakukan rekruitmen hakim maka akan terjadi politik balas budi ini tentu sangat tendensius, setelah seseorang menjadi hakim maka tidak ada hubungan struktural dan administratif antara Komisi Yudisial dengan hakim-hakim tersebut. Oleh karena itu menjadi pertanyaan apabila ada yang mengatakan bahwa kebersamaan bersama antara Mahkamah Agung dan Komisi Yudisial dalam melakukan seleksi pengangkatan hakim bisamempengaruhi kebebasan hakim. ${ }^{13}$

Pelaksanaan seleksi pengangkatan hakim yang dilakukan oleh Mahkamah Agung dan Komisi Yudisial merupakan sesuatu yang baik berdasarkan prinsip check and balances, untuk menghasilkan pilihan yang tepat, yang lebih obyektif dengan memenuhi kriteria-kriteria dan syarat-syarat yang obyektif pada pilihan hakim yang berintegritas dan berkepribadian yang tidak tercela, adil, profesional dan pengalaman dibidang hukum sehingga mencapai dari tujuan yang telah diamanatkan oleh UUD $1945 .{ }^{14}$

12 Keterangan Ahli Saldi Isra dalam Sidang Perkara No. 43/PUU-XIII/2015 tentang Pengujian UU No. 49 Tahun 2009 Tentang Perubahan Kedua Atas UU No. 2 Tahun 1986 Tentang Peradilan Umum, UU No. 50 Tahun 2009 Tentang Perubahan Kedua Atas UU No. 7 Tahun 1989 Tentang Peradilan Agama dan UU No. 51 Tahun 2009 Tentang Perubahan Kedua Atas UU No. 5 Tahun 1986 Tentang Peradilan Tata Usaha Negara.

13 Wicaksono, E., et.al. (2016).“Tinjauan Yuridis Putusan Mahkamah Konstitusi No.43/PUUXIII/2015 Tentang Inkonstitusionalitas Kewenangan Komisi Yudisial Dalam Melakukan Rekruitmen Hakim Bersama Mahkamah Agung”, Diponegoro Law Journal, 5 (4), 1-19, h. 15.

14 Sihaloho, M. (2015). "Seleksi Pengangkatan Hakim Dalam Sistem Peradilan Indonesia : Kajian

$$
274 \text { | S A S I Vol. } 26 \text { No.2, April - Juni } 2020
$$


Menurut penulis terlibatnya Komisi Yudisial dalam seleksi pengangkatan calon hakim merupakan langkah yang tepat. Terlibatnya Komisi Yudisial sebagai institusi diluar Mahkamah Agung dan fungsinya terkait dengan kekuasaan kehakiman justru akan memperkuat Institusi tersebut dalam proses pengangkatan calon hakim, sehingga diharapkan akan dihasilkan hakim-hakim yang berintegritas, bersih dan kompeten. Kalau ditelusuri secara historis dalam pembahasan perubahan UUD 1945 oleh PAH I BP MPR, sebetulnya ide tentang keterlibatan Institusi diluar Mahkamah Agung dalam melakukan rekruitmen hakim banyak disuarakan oleh anggota PAH I BP MPR, Seperti Pataniari Siahaan, Harjono dan Jacob Tobing. Bahkan disitu secara spesifik disebutkan bahwa rekruitmen hakim itu dilakukan oleh Komisi Yudisial.

Pataniari Siahaan dari F-PDI Perjuangan mengusulkan agar dalam Bab IX UUD 1945 seyogyanya ada masalah lembaga yang menangani bagaimana melakukan seleksi/rekruitmen terhadap hakim agung dan terhadap hakim-hakim yang lebih layak dan tepat. Untuk itu ia mengusulkan beberapa hal, berikut uraiannya:

"Disini kami ingin mengusulkan bahwa dalam Bab IX ini seyogyanya ada masalah lembaga-lembaga yang menyangkut MA, ada menangani masalah-masalah konstitusi tapi juga ada lembaga yang menangani bagaimana melakukan seleksi rekrutmen terhadap Hakim Agung dan terhadap hakim-hakim karena sekarang kita sama-sama sepakat saya pikir mutu daripada hakim kita adalah hakim kita masih tetap menjadi pertanyaan di kalangan masyarakat. Mekanisme rekrutmen seyogyanya ditangani oleh satu lembaga yang lebih layak dan tepat untuk mengatasi tersebut, sehingga bukan hanya masalah urutan masa kerja atau birokratis saat dia menentukan perilaku mereka. Karena secara kewenangan mereka adalah mandiri, sehingga kami nanti di dalam bagian Bab IX kami usulkan kita ada bicara masalah Mahkamah Agung, ada masalah Mahkamah Konstitusi dan kami tetap mengusulkan satu Komisi Yudisial yang melakukan rekruitmen dan seleksi terhadap siapa calon-calon Mahkamah Agung yang selama ini masih dipegang oleh DPR". 15

Dalam Rapat Pleno lanjutan PAH I BP MPR Harjono dari F-PDI Perjuangan mengatakan bahwa pengangkatan, KY bertugas menseleksi Hakim Agung. Untuk itu, Harjono mengharapkan agar KY digunakan untuk mengubah cara rekruitmen hakim, berikut uraiannya ;

"Pada persoalan rekruitmen Hakim, Komisi Yudisial memang dalam ketentuan ini masih terbatas untuk menseleksi calon-calon Hakim Agung, satu pertanyaan kalau Hakim Agung sekarang itu sudah ada kemungkinan masuknya non karier, pertanyaan berikutnya kenapa itu hanya pada Hakim Agung saja, pada Hakim tinggi dan pada Hakim tingkat pertama apa juga tidak dibuka mekanisme seperti itu, apa bedanya sebetulnya. Menurut saya, titik yang paling kritis sebetulnya bukan di MA, sebetulnya di Pengadilan Tingkat I dan Tingkat II, kalau di Pengadilan Tingkat I dan Tingkat II keadilan sudah dirasakan itu harus kasasi itu bisa dikurangi. Oleh karena itu, bicara tentang persoalan Komisi Yudisial, barangkali mulai kita pikirkan apakah juga ini tidak kita gunakan untuk mengubah cara rekruitmen hakim kita. Yang pertama dia ingin mencari pekerjaan nyangkut di Pegawai Negeri, setelah

Putusan Mahkamah Konstitusi Nomor. 43/PUU-XII/2015”, Jurnal Wawasan Hukum, 33 (2), 204-218, h. $216-217$.

15

(2008). Naskah Komprehensif Perubahan UUD 1945 ; Latar Belakang, Proses dan Hasil Pembahasan 1999-2002, Buku VI Kekuasaan Kehakiman, Jakarta : Sekretariat Jenderal Mahkamah Konstitusi RI, h. 440-441. 
menjadi Pegawai Negeri tidak masuk Panitera kebetulan dia masuk sebagai hakim, ini semua kita hilangilah semacam itu. Oleh karena itu, profesi hakim seharusnya memang diniatkan sebagai hakim. Di luar negeri untuk jadi Hakim dari Pengacara bisa, karena dia konsisten dengan pendapat-pendapatnya, ini pantas untuk menjadi seorang Hakim, tetapi disini Hakim harus menjadi Pegawai Negeri dari masuk Hakim sampai Pensiun Hakim itulah ladangnya, barangkali untuk masa jabatan Hakim juga kita batasi tidak masuk sampai pensiun, Hakim diberikan tertentu saja mungkin 5 (lima) tahun setelah itu dikembalikan lagi kepada Komisi Yudisial, kalau dia ingin jadi Hakim lagi, apakah dia masih pantas untuk bisa diterima menjadi Hakim atau tidak, ini saya kira juga berhubungan dengan rekruitmen, ada persoalanpersoalan keterbukaan, ada persoalan-persoalan aset stabilitas pada dunia hukumnya, juga ada persoalan-persoalan kapabilitas yang dipertimbangkan ketimbang rekruitmen pada sekarang ini. Jadi itulah pendapat saya tentang Komisi Yudisial". ${ }^{16}$

Demikian pula dengan Jacob Tobing dari F-PDI Perjuangan yang mengatakan, bahwa rekruitmen adalah suatu tempat yang paling krusial dalam menentukan kehandalan daripada hakim itu. Oleh karena itu, Jacob Tobing mengusulkan agar kewenangan KY menseleksi hakim juga meliputi Hakim Tinggi, Hakim Pengadilan Negeri. Berikut uraiannya ;

“ Kami juga ingin sedikit lebih elaborasi tentang pentingnya Komisi Yudisial, Hakim bukan Pegawai Negeri, Hakim membawa yang hak, menegakkan yang hak, keadilan, dan kita mengatakan selama ini dia sebetulnya Pejabat Negara walaupun Hakim di Pengadilan Negeri dan tidak kita katakan Hakim Pengadilan Negeri bawahan dari atasannya lagi atasannya lagi masing-masing ini otoritasnya sendiri dan selalu amar putusannya mengatakan demi keadilan yang berdasarkan Ketuhanan Yang Maha Esa tidak pernah dikatakan demi Atasan saya tidak dikatakan begitu. Jadi sangat-sangat sentral dan penting kedudukannya di dalam negara yang kita dambakan dan kita bangun menjadi negara yang menegakkan hukum, supermasi hukum, oleh karena itu dia harus mempunyai persyaratanpersyaratan biasa, kemampuan-kemampuan inteligensi, profesi, disiplin ilmu sebagai seorang penguasa Ilmu Hukum tetapi juga mempunyai accounbility yang menegakkan integritasnya, oleh karena itu yang kami sarankan tentang Komisi Yudisial sebenarnya adalah menyangkut bukan hanya Hakim Agung seluruhnya, Hakim Agung, Hakim Tinggi, Hakim Pengadilan Negeri mereka semua adalah Hakim yang tidak bisa tiap tahun dimintai bertanggungjawab kepada MPR misalnya atau kepada siapa begitu tetapi dia bertanggungjawab kepada sebetulnya praktis dirinya sendiri, karena rekruitmen adalah suatu tempat yang paling krusial dalam menentukan kehandalan daripada hakim itu". ${ }^{17}$

Rumusan akhir dari PAH I MPR terhadap Pasal 24B ayat (1) UUD 1945 adalah Komisi Yudisial bersifat mandiri yang berwenang mengusulkan pengangkatan dan pemberhentian Hakim Agung serta hakim lain (dengan memperhatikan masukan dari masyarakat/berdasarkan masukan dari masyarakat).

Dari uraian tersebut diatas sebetulnya jelas bahwa para anggota PAH MPR telah

16 (2008). Naskah Komprehensif Perubahan UUD 1945; Latar Belakang, Proses dan Hasil Pembahasan 1999-2002, Buku VI Kekuasaan Kehakiman, Jakarta : Sekretariat Jenderal Mahkamah Konstitusi RI, h. 443-444.

17

(2008). Naskah Komprehensif Perubahan UUD 1945 ; Latar Belakang, Proses danHasil Pembahasan 1999-2002, Buku VI Kekuasaan Kehakiman, Jakarta : Sekretariat Jenderal Mahkamah Konstitusi RI, h. 444-445. 
sepakat bahwa rekruitmen hakim itu dilakukan oleh Komisi Yudisial, walaupun akhirnya pada saat penetapan oleh MPR redaksinya berubah.

Menurut penulis keterlibatan Komisi Yudisial dalam seleksi pengangkatan calon hakim tidak akan mengganggu Independensi Kekuasaan Kehakiman dan Independensi hakim. Hakim akan terganggu Independensinya kalau Komisi Yudisial atau Institusi lain intervensi atau campur tangan dalam hal teknis yustisial yaitu memeriksa, mengadili dan memutus suatu perkara. Kalau keterlibatan Komisi Yudisial dalam rekruitmen hakim akan mengganggu independensi hakim, bagaimana dengan hakim agung yang seleksinya dilakukan Komisi Yudisial. Independensi hakim dan kekuasaan kehakiman harus diikuti dengan akuntabilitas dan salah satu bentuk pertanggung jawaban kepada publik adalah keterlibatan Institusi lain, dan dalam hal ini adalah Komisi Yudisial dalam melakukan seleksi pengangkatan calon hakim.

Dalam konsep pemisahan kekuasaan dalam suatu negara modern saat ini sebetulnya checks and balances antar cabang kekuasaan atau lembaga negara mutlak diperlukan, namun dewasa ini dalam pelaksanaannya di Indonesia menemui banyak masalah karena dianggap suatu ancaman untuk menjatuhkan lembaga negara lain dan adanya ego sektoral. Hal ini dapat dilihat antara Mahkamah Agung dan Komisi Yudisial. ${ }^{18}$

Menurut Falaakh, kekuasaan kehakiman yang merdeka perlu dipahami bahwa kekuasaan kehakiman ditekankan sebagai kebebasan hakim dan lembaga yudikatif dalam menegakkan hukum dan keadilan atau diranah teknis-yustisi. Berarti pertama, pembatasan terhadap kekuasaan kehakiman hanya dapat ditentukan ditingkat konstitusi dan tidak boleh ditentukan hanya dengan undang-undang. Kedua, yudikatif tidak bebas diranah non yustisi (kepegawaian, administrasi dan keuangan). ${ }^{19}$ Pelibatan Komisi Yudisial dalam rekruitmen hakim dimaksudkan untuk menjamin proses seleksi yang dapat menghasilkan hakim yang berkualitas dan berintegritas. Selama lembaga pengadilan yang masih belum bersih, transparan, akuntabel dan berintegritas, Komisi Yudisial masih diperlukan. ${ }^{20}$

Dampak yang ditimbulkan akibat adanya putusan Mahkamah Konstitusi No. 43/PUU-XIII/2015, Komisi Yudisial tidak mempunyai wewenang lagi dalam pengangkatan hakim peradilan tingkat pertama. Mahkamah Konstitusi mengembalikan kewenangan pengangkatan hakim kepada Mahkamah Agung dengan mekanisme satu atap. Sehingga wewenang dari Komisi Yudisial hanya sebatas mengusulkan pegangkatan hakim agung dan hakim ad hoc dalam lingkungan Mahkamah Agung. ${ }^{21}$ Kondisi ini sangat berbeda kalau dibandingkan dengan Komisi Yudisial di negara-negara Eropa. Komisi Yudisial di negara Eropa mempunyai kewenangan untuk melakukan rekruitmen hakim, pendidikan, rotasi, mutasi dan promosi hakim. ${ }^{22}$

Praktis setelah adanya keputusan Mahkamah Konstitusi ini kewenangan untuk

18 Rahmatullah, I. dan Agusty, R. Z. (2016). "Memperkuat Hubungan Antar Lembaga Negara Dalam Bingkai Negara Hukum”, Jurnal Salam, 3 (2), 231-244, h. 241.

19 Suanro. (2016). "Kewenangan KomisiYudisial DalamTafsir Mahkamah Konstitusi ; Kajian Putusan Mahkamah Konstitusi Nomor 43/PUU-XIII/2015 ”, Jurnal Yudisial, 9 (2), 131-150, h. 147.

20 Faizal, A. (2016). “Politik Hukum Perlindungan Hakim”, Jurnal Cita Hukum, 4 (1), 1-14, h. 3.

21 Ulya, Z. (2016). "Pembatalan Kewenangan Komisi Yudisial Dalam Rekruitmen HakimDikaitkan Dengan Konsep Independensi Hakim (Studi Putusan Mahkamah Konstitusi Nomor 43/PUU-XIII/2015 ", Jurnal Mimbar Hukum, 28 (3), 482-496, h. 493.

22 Suparto. (2017). "Kedudukan dan Kewenangan Komisi Yudisial Republik Indonesia dan Perbandingannya Dengan Komisi Yudisial Di Beberapa Negara Eropa ”, Jurnal Hukum dan Pembangunan, 47 (4), 497-516, h. 507 dan Voermans, W. (2002). Komisi Yudisial Di Beberapa Negara Uni Eropa, Jakarta : LeIP, 2002, h. 12-13. 
merekrut hakim hanya boleh dilakukan oleh pihak Mahkamah Agung sendiri tanpa campur tangan pihak lain. Mahkamah Agung semakin menjadi lembaga superbody tanpa pengawasan dari Komisi Yudisial dalam rekruitmen hakim. Kondisi ini menjadi tantangan bagi Mahkamah Agung bahwa dengan mereka melakukan rekruimen sendiri, Mahkamah Agung harus menjamin agar bisa mendapatkan hakim yang baik, jujur, bersih dan berintegritas agar bisa menegakkan hukum dan keadilan bagi masyarakat. ${ }^{23}$

Tetapi bagaimanapun juga putusan Mahkamah Konstitusi telah dikeluarkan dan Mahkamah Konstitusi sebagai Institusi yang oleh UUD 1945 diberi kewenangan untuk menguji UU terhadap UUD telah melakukan tugasnya, sehingga apapun hasilnya harus dihormati dan ditaati.

\section{PE N T U P}

Putusan Mahkamah Konstitusi No. 43/PUU-XII/2015 menyatakan bahwa keterlibatan Komisi Yudisial dalam rekrutmen hakim mengganggu independensi kekuasaan kehakiman sehingga dinyatakan inkonstitusional. Sejatinya keterlibatan Komisi Yudisial dalam seleksi pengangkatan calon hakim tidak akan mengganggu Independensi Kekuasaan Kehakiman dan Independensi hakim. Hakim akan terganggu Independensinya kalau Komisi Yudisial atau Institusi lain intervensi atau campur tangan dalam hal teknis yustisial yaitu memeriksa, mengadili dan memutus suatu perkara. Kalau keterlibatan Komisi Yudisial dalam rekruitmen hakim akan mengganggu independensi hakim, bagaimana dengan hakim agung yang seleksinya dilakukan Komisi Yudisial. Independensi hakim dan kekuasaan kehakiman harus diikuti dengan akuntabilitas dan salah satu bentuk pertanggung jawaban kepada publik adalah keterlibatan Institusi lain, dan dalam hal ini adalah Komisi Yudisial dalam melakukan seleksi pengangkatan calon hakim. Pelaksanaan seleksi pengangkatan hakim setelah adanya putusan Mahkamah Konstitusi No. 43/PUU-XII/2015 kembali lagi ke Mahkamah Agung, dengan demikian Komisi Yudisial tidak mempunyai wewenang lagi dalam pengangkatan hakim peradilan tingkat pertama. Komisi Yudisial hanya berwenang dalam hal mengusulkan pegangkatan hakim agung dan hakim ad hoc dalam lingkungan Mahkamah Agung.

\section{DAFTAR PUSTAKA}

\section{Buku}

[1] Suparto. (2017). Dinamika Hubungan Antara Mahkamah Agung Dengan Komisi Yudisial Republik Indonesia, Jakarta : Bina Karya.

[2] Syafrinaldi,ed.(2015). Hukum dan Teori Dalam RealitaMasyarakat, Pekanbaru : UIR Press.

[3] Syafrinald,. ed. (2018). Problematika Hukum Indonesia Teori dan Praktek, Depok : Raja Grafindo Persada.

[4] Voermans, W. (2012). Komisi Yudisial Di Beberapa Negara Uni Eropa, Jakarta : LeIP.

23 Wicaksono, E., et. al., (2016).“Tinjauan Yuridis Putusan Mahkamah Konstitusi No.43/PUUXIII/2015 Tentang Inkonstitusionalitas Kewenangan Komisi Yudisial Dalam Melakukan Rekruitmen Hakim Bersama Mahkamah Agung”, Diponegoro Law Journal, 5 (4). 1-19, h. 13. 


\section{Jurnal}

[5] Faizal, A. (2016). "Politik Hukum Perlindungan Hakim”, Jurnal Cita Hukum, 4 (1), $1-14: 3$

[6] Mukuan, C. (2016). "Kewenangan Komisi Yudisial Dalam Perekrutan Hakim Menurut Undang-Undang No. 22 Tahun 2004 jo Undang-Undang No. 18 Tahun 2011 Tentang Komisi Yudisial", Jurnal Lex Administratum, IV (1), 5-12 : 5.

[7] Permana, T.C.I. (2014). "Eksistensi dan Peran Komisi Yudisial : Pengkajian Konteks Filosofi, Sejarah dan Tujuan Pembentukannya Dalam Dinamika Ketatanegaraan Indonesia", Jurnal Hukum dan Peradilan, 3 (1), 85-100 : 96.

[8] Rahmatullah, I. dan Agusty, R.Z. (2016). "Memperkuat Hubungan Antar Lembaga Negara Dalam Bingkai Negara Hukum", Jurnal Salam, 3 (2), 231-244 : 241.

[9] Sihaloho, M. (2015). "Seleksi Pengangkatan Hakim Dalam Sistem Peradilan Indonesia : Kajian Putusan Mahkamah Konstitusi Nomor. 43/PUU-XII/2015”, Jurnal Wawasan Hukum, 33 (2), 204-218 : 216-217.

[10] Suanro. (2016). "Kewenangan Komisi Yudisial Dalam Tafsir Mahkamah Konstitusi ; Kajian Putusan Mahkamah Konstitusi Nomor 43/PUU-XIII/2015 ”, Jurnal Yudisial, 9 (2), 131-150: 147

[11] Suparto. (2017). "Kedudukan dan Kewenangan Komisi Yudisial Republik Indonesia dan Perbandingannya Dengan Komisi Yudisial Di Beberapa Negara Eropa”, Jurnal Hukum dan Pembangunan,47 (4), 497-516 : 507.

[12] Ulya, Z. (2016). "Pembatalan Kewenangan Komisi Yudisial Dalam Rekruitmen Hakim Dikaitkan Dengan Konsep Independensi Hakim (Studi Putusan Mahkamah Konstitusi Nomor 43/PUU-XIII/2015 ", Jurnal Mimbar Hukum, 28 (3), 482-496 : 493.

[13] Wicaksono, E., et.al. (2016). "Yuridis Putusan Mahkamah Konstitusi No.43/PUUXIII/2015 Tinjauan Tentang Inkonstitusionalitas Kewenangan Komisi Yudisial Dalam Melakukan Rekruitmen Hakim Bersama Mahkamah Agung“, Diponegoro Law Journal, 5 (4), 1-19: 13,15. 